\title{
Losses due to lenticel rot are an increasing concern for Kern County potato growers
}

by James J. Farrar, J. Joseph Nunez and

R. Michael Davis

In recent years, lenticel rot of potato tubers, caused by the bacterium Erwinia carotovora subsp. carotovora, has become an economically important postharvest disease for Kern County growers. Disease symptoms are sunken and rotted tissue surrounding tuber lenticels, which develop after harvest and packing. In the field, the bacterium also causes Erwinia early dying, characterized by wilt and progressive necrosis of leaves, eventually resulting in potato plant death. This study confirms Erwinia carotovora subsp. carotovora as the causal agent of both problems in Kern County and establishes the link between the field and postharvest diseases. Control of both diseases is difficult and relies on the integration of cultural methods, from preplant seed-piece handling to postharvest processing.

W ith a $\$ 186$ million market value (similar to onions), the California potato industry is small compared to that of potato-producing giants like Idaho and Washington, but potatoes are certainly an important regional crop. Kern County is California's largest potato-growing region, with 16,470 acres (6,665 hectares) planted in 2007 to red, white, russet and chipping varieties. Total harvest from Kern County was 432,000 metric tons $(5,261,800$ hundredweight [cwt]) in 2007, with total sales of about $\$ 60$ million.

Potato cultivation in this region occurs during two seasons, the spring season from January to June and the fall season from August to December. Excessive postharvest losses, especially after potato shipments have reached the marketplace, have resulted in significant

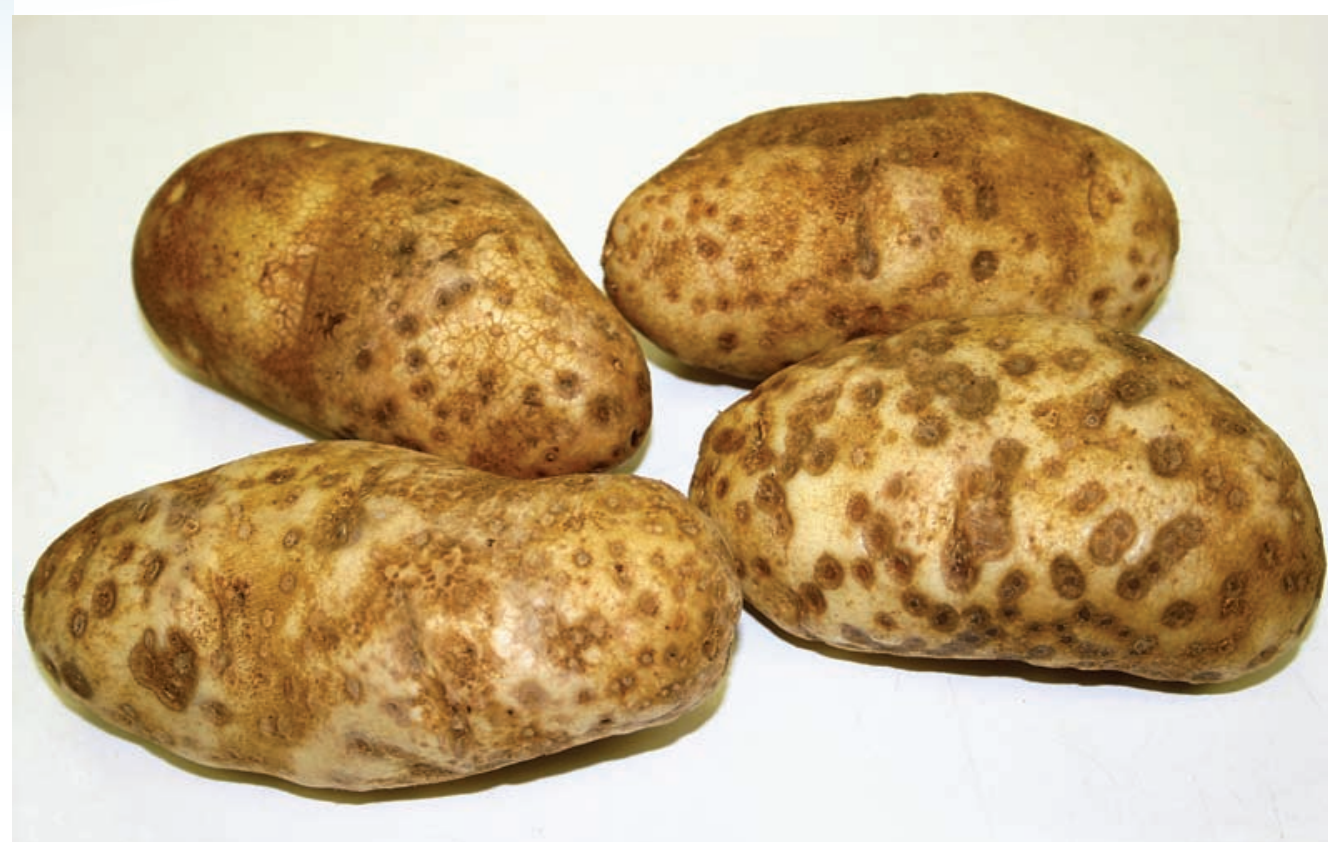

Postharvest lenticel rot has been known in California for nearly a century, but did not reach damaging levels until the late 1990s. The rot occurs around the small ovals where air is exchanged on the potato surface.

economic losses to growers in the San Joaquin Valley. Produce buyers for large national grocery outlets carefully scrutinize California potatoes for sunken and rotted tissue surrounding tuber lenticels, the small oval areas on the surface of a potato where air exchange occurs. Unsightly rotted or discolored lenticel tissues render the potatoes unmarketable, and occasionally shipments of California potatoes are dumped.

Lenticel rot has probably been in California since potato production became established in Kern County in 1912, but did not reach damaging levels until the late 1990s. Currently, we have observed that lenticel rot affects an estimated $30 \%$ of harvested potato tubers in Kern County. In the San Joaquin Valley, the warm climate and heavy irrigation of the crop may exacerbate this problem. Recently, we discovered that the same causal organism of lenticel rot is associated with a decline of potato plants called Erwinia early dying.

\section{Description of symptoms}

Lenticel rot. Lenticel rot is characterized by dry and sunken discolored lesions surrounding potato tuber lenti- cels. Lesions begin as swollen areas surrounding the lenticels or as small areas of white, puffy tissue pouring forth from the lenticels. Usually, affected tissue does not extend deeper than $1 / 8$ inch ( 3 millimeters) into the tuber. Neighboring lesions may coalesce to form larger, irregularly shaped sunken areas. Symptoms are most often noticeable 4 to 10 days after the harvest and packaging of potatoes. If potatoes are stored wet and conditions are warm, a soft rot of the surrounding tissue may ensue, and extensive decay of the entire tuber may occur in extreme cases. Often, these symptoms become apparent in tubers during transportation to market.

Erwinia early dying. Lenticel rot is often associated with a potato plant disease called Erwinia early dying (Powelson 1985). The initial symptom is wilting of the leaflets or whole leaves on plants in adequately irrigated fields. Leaves later become necrotic (dead) beginning at the margins. Plants may defoliate from the base upward and often senesce (decline and die) prematurely. The stems appear healthy externally, but the vascular system and pith of the lower stem - extending upward from 
the junction with the seed piece (the piece of a potato tuber that is planted as seed) - are tan to brown in color. A soft rot of the seed pieces occurs, and yields are negatively affected.

Verticillium early dying. Symptoms of Erwinia early dying are similar to Verticillium early dying, which is caused by Verticillium spp. and lesion nematodes (Powelson 1985; Rowe et al. 1987). Verticillium wilt is common in other potato-growing regions of the United States. Verticillium spp. are common fungal pathogens of alfalfa, cotton, cucurbits, pepper and tomatoes but are only occasionally recovered from potato in the San Joaquin Valley. Lesion nematodes (Pratylenchus spp.) are common pests of alfalfa and orchard crops in the San Joaquin Valley but are also seldom observed in potato fields. Symptoms of Verticillium early dying are leaf chlorosis (yellowing) progressing from the lower leaves to the upper leaves, leaf necrosis and light brown discoloration of the vascular tissue. In contrast to Verticillium early dying, Erwiniainduced early dying is always associated with rotted seed pieces, warm soil temperatures and high soil moisture.

Seed-piece syndrome. Erwinia early dying can also be confused with a problem that Kern County potato growers call toxic seed-piece syndrome. This problem is caused by planting physiologically old seed and is characterized by rapid emergence, multiple stems, small weak plants, numerous small tubers, lower yields and early senescence. Physiologically "old" seed is not clearly defined, but we have observed these symptoms on plants grown from seed kept in storage for 1 year. Conversely, the characteristics of plants from young seed include slow emergence, few main stems, vigorous large plants, fewer larger tubers, higher yields and delayed senescence. Erwinia early dying affects plants grown from young or old seed.

\section{Causal agents of potato disease}

Due to the association between early dying symptoms in the field and postharvest lenticel rot symptoms, we decided to carefully examine the causal agents for both diseases.

Lenticel rot. We isolated Erwinia carotovora subsp. carotovora (more recently called Pectobacterium carotovorum subsp.

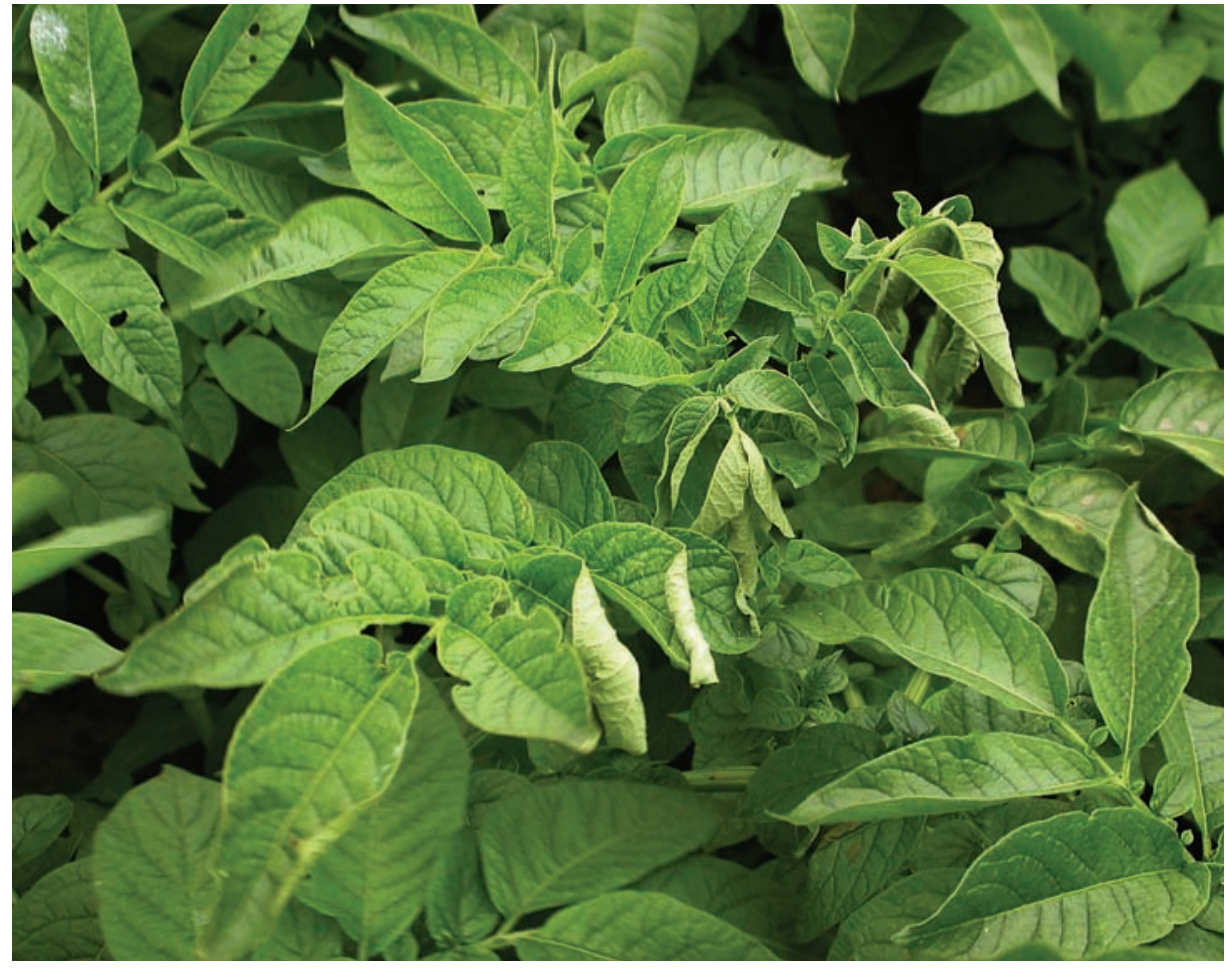

The initial symptoms of Erwinia early dying - a potato plant disease associated with lenticel rot - include leaf wilt in adequately irrigated fields. carotovorum) from symptomatic lenticels. Three-hundred tubers were collected over 3 years from commercial potato fields in Kern County. In addition, 30 packing sheds.

The surfaces of tubers were washed thoroughly with soap and water, then rinsed well in deionized water and air-dried. The tissue surrounding the affected lenticels was excised, dipped in $0.5 \%$ sodium hypochlorite for 1 minute, rinsed in sterilized water and macerated in a few drops of sterilized water. Approximately 10 microliters of each suspension was spread onto King's B and nutrient agar plates. Plates were incubated at $77^{\circ} \mathrm{F}\left(25^{\circ} \mathrm{C}\right)$ and evaluated after 48 hours. The number of visibly different colonies (based on morphology) present on each plate was noted. Unique colony types occurring on multiple plates were subcultured onto nutrient agar. Genomic DNA was then extracted from these isolates (Qiagen DNeasy kit, Qiagen, Valencia, Calif.) and the $16 \mathrm{~S}$ rDNA gene was amplified tubers were collected postharvest from using universal bacterial primers fp1 and rd1 (Sessitch et al. 2001). Sequences obtained from these PCR (polymerase chain reaction) products were identified based on a comparison of international DNA-sequence databases.

Fifty isolates were tested for their ability to cause tuber soft rot by stab-inoculating flame-sterilized tuber slices with twice-autoclaved toothpicks smeared in bacteria. The tuber slices were then incubated at $77^{\circ} \mathrm{F}\left(25^{\circ} \mathrm{C}\right)$ for 24 hours. In addition, the pathogenicity of isolates in lenticels was determined by submerging washed tubers in a pressurized ( 30 pounds per square inch) container of a suspension of $E$. carotovora subsp. per milliliter). Inoculated tubers were then wrapped in a moist paper towel and placed in closed plastic bags to exclude oxygen. After 5 and 10 days, tubers were removed and examined for lenticel rot. Bacteria were reisolated from lenticel rot tissues and reidentified as E. carotovora subsp. carotovora. carotovora cells (approximately $10^{6}$ cells

\section{The bacteria that cause lenticel rot and Erwinia early dying are common on the surface of potato tubers, in soil and in surface irrigation water.}




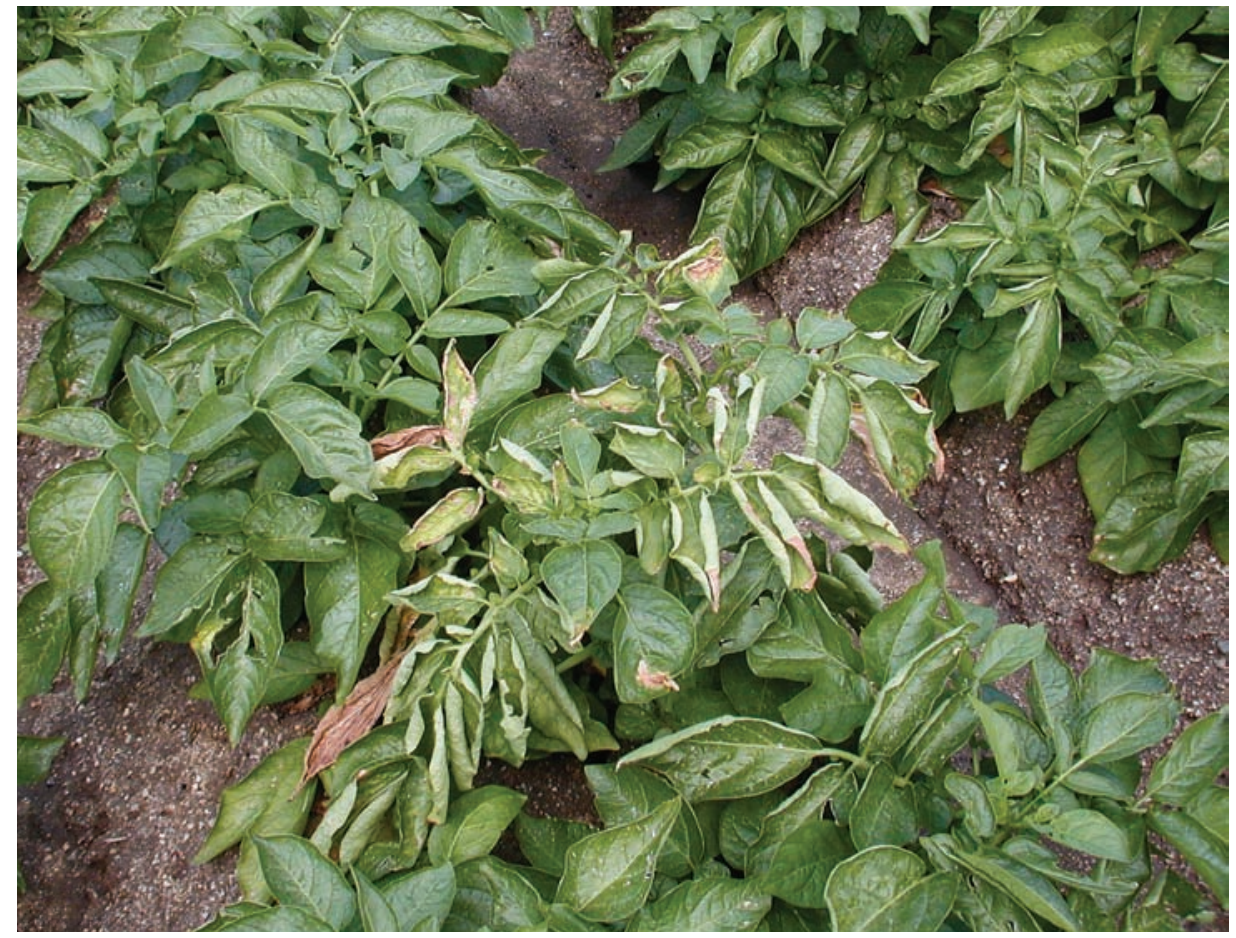

As Erwinia early dying progresses, leaves wilt further and die, sometimes killing the potato plant. When potatoes from these diseased plants are washed, bacteria can get into the lenticels and cause them to rot.

Erwinia early dying. Erwinia early dying is caused predominantly by Erwinia cartovora subsp. carotovora (Ecc) and to a lesser extent by Erwinia chrysanthemi (Echr). The causal agent of blackleg of potato, Erwinia carotovora subsp. atroseptica, is not associated with Erwinia early dying. Blackleg is characterized by a black to brown soft rot of the stems extending from the seed piece upward. Potato plants with blackleg are typically stunted and usually die prior to canopy closure in the San Joaquin Valley.

We determined the causes of early dying by isolating the causal agents from diseased plants and inoculating healthy plants. In a random collection of more than 100 plants with symptoms of Erwinia early dying and blackleg in 13 fields, bacteria associated with discolored stems and seed pieces were identified by fatty-acid methyl-ester analysis (MIDI Microbial Identification System, ver. 3.8, Newark, Del.) and standard physiological identification techniques (Dickey and Kelman 1988).

Sixty-two isolates were identified; 13 were E. carotovora subsp. atroseptica (Eca), 42 were E. carotovora subsp. carotovora (Ecc), two were Erwinia chrysanthemi (Echr) and five were Pseudomonas fluorescens (=P. marginalis). Fungi were not generally isolated from the affected stems, and nematodes were not observed on the affected plants. In Kern County, Verticillium spp. and lesion nematodes rarely affect potatoes. The absence of Verticillium and nematode problems may be due to routine soil fumigation with metam sodium, which is standard practice for vegetable growers in the region.

Suspensions of bacterial isolates were injected by syringe into the stems of 30 12- to 15-week-old greenhousegrown potato plants. Sterile water was used as a control. Symptoms were noted after 2 to 3 days. Syringe-inoculated greenhouse plants developed two distinct sets of symptoms. Plants inoculated with Eca isolates developed symptoms of blackleg, which are leaf wilt, a soft black stem rot and stem collapse. Plants inoculated with the Ecc or Echr isolates developed leaf wilt, an external brown lesion at the inoculation point, brown discoloration of the vascular system and soft rot of the pith. The vascular system discoloration and pith rot extended up to several centimeters above and below the inoculation point. Bacteria were reisolated and reidentified for confirmation. The bacteria re- isolated from syringe-inoculated plants was identical to the respective original isolates. Therefore, Ecc and Echr inoculations resulted in Erwinia early dying symptoms and Eca inoculations resulted in blackleg symptoms.

\section{Epidemiology}

The bacteria that cause lenticel rot and Erwinia early dying are common on the surface of potato tubers, in soil and in surface irrigation water (Romberg et al. 2002; Harrison et al. 1987). Potatoes can be freed of Erwinia contamination through tissue culture but will reacquire the bacteria when planted in soil. While soil levels of Ecc are highest immediately after the production of a susceptible crop like potatoes, carrots or onions, low background levels of Ecc are always present (Powelson and Apple 1984).

In Kern County, the major potato planting occurs in January and February for harvest in June. Potatoes are planted in cool weather, and the air and soil temperatures increase as the season progresses. Because potatoes are grown in sandy soil and are a shallowrooted crop, growers irrigate frequently, especially when temperatures are warm. To our knowledge, there is no other large potato-producing region in the United States where the air temperature becomes as warm late in the production season. Warm temperatures and moisture are known to promote Erwinia soft-rot diseases.

During the lifting and harvest of potatoes, tubers can be smeared with soft-rot bacteria from decayed seed pieces. At the packing shed, potatoes are first dumped into a wash tank to clean them. Surface bacteria can be pushed into lenticels by hydrostatic (exerted by water) pressure in the wash tanks (Bartz and Kelman 1985). Hydrostatic pressure increases with increasing depth of the tank. Once inside the lenticel tissue, the bacteria multiply and cause lenticel rot.

\section{Integrated controls for soft rot}

There are no effective chemical controls for any of the soft-rot Erwinias. The management of all Erwinia diseases of potatoes involves integrating cultural controls from seed handling to harvest. Seed tubers should be handled carefully to avoid bruising or any other 


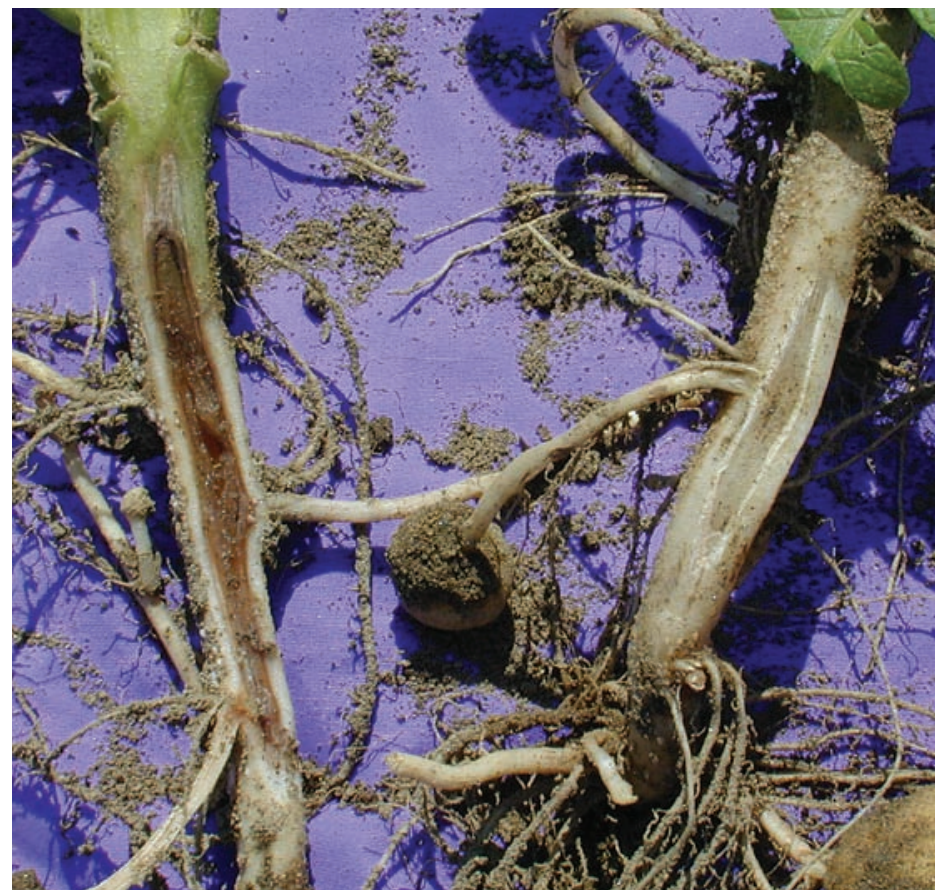

A rotten lower potato stem with Erwinia early dying disease (left) and a healthy stem (right).

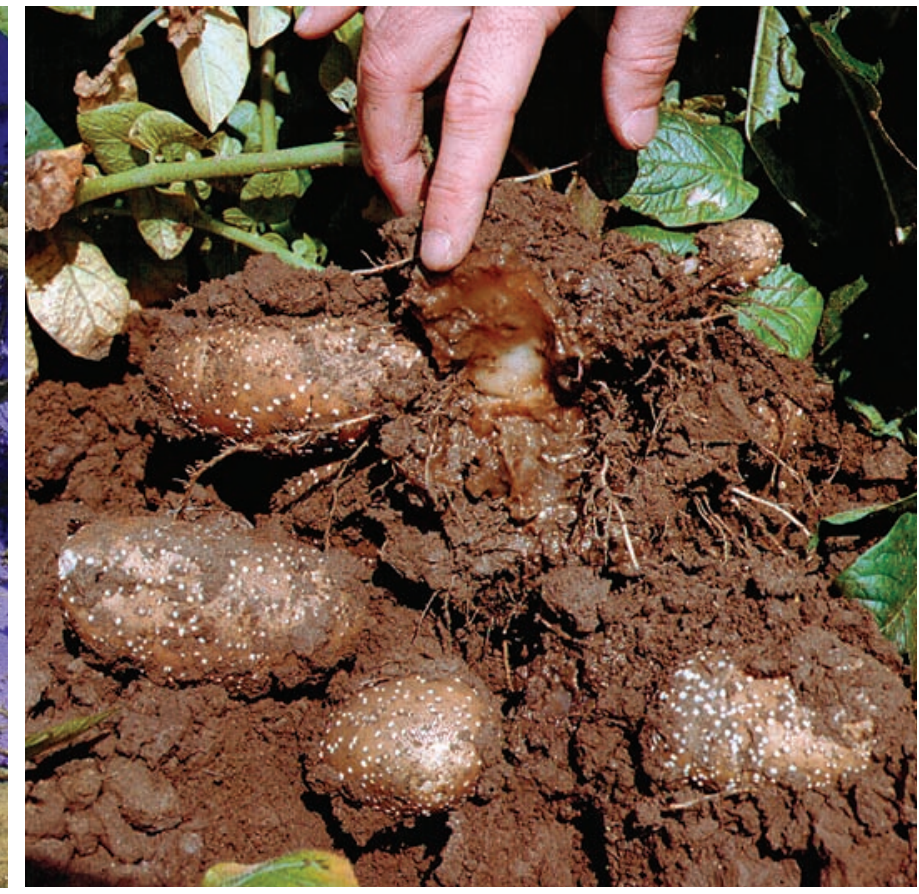

Seed-piece decay is associated with Erwinia leaf and stem symptoms; note the open lenticels on the potato tubers. mechanical injuries. Cut seed should be allowed to heal to provide a barrier against bacteria. Management of water and soil fertility throughout the growing season is critical to reduce the incidence of disease. Tubers should be harvested when the skins are set and the lenticels are closed, since breaks in the skins and open lenticels are good avenues for infection. Since soft-rot Erwinias can be drawn into tubers through open lenticels as the warm tubers are washed in cool water during the dump wash process, tubers should not be exposed to hydrostatic pressure from either deep tanks or tall rises in flumes (pipes for moving tubers from the wash tank) in the packing sheds. Care should be taken to avoid scuffing, cutting or bruising potatoes during sorting and packaging. Finally, potatoes should be stored dry and cool.

Good calcium fertility management in the field also reduces postharvest Erwinia losses. Calcium is integral to maintaining cell-wall rigidity and it counters the activity of soft-rot Erwinia enzymes, which degrade the cell walls. Soluble calcium must be in the soil surrounding developing tubers, since tubers receive little calcium from the plant transpiration stream. Water and minerals taken up from the soil by the roots are drawn to plant parts with high evaporation rates. Since the developing tubers are in the soil, they have a low evaporation rate, therefore little calcium moves from the roots to the developing tubers.

Antimicrobial agents such as peroxyacetic acid and hydrogen peroxide, applied as a final rinse in the packing process, are effective in reducing the tuber surface populations of soft-rot organisms, resulting in less postharvest loss to lenticel rot. These agents can reduce lenticel rot, but there are no effective chemical controls for Erwinia early dying (J. Nunez and M. Davis, unpublished). Erwinia early dying is distinct from early dying due to Verticillium spp. and lesion nematodes, which has been re-

\section{References}

Bartz JA, Kelman A. 1985. Infiltration of lenticels of potato tubers by Erwinia carotovora subsp. carotovora under hydrostatic pressure in relation to bacterial soft rot. Plant Dis 69:69-74.

Dickey RS, Kelman A. 1988. Erwinia, 'Carotovora' or soft rot group. In: Schaad NW (ed.). Laboratory Guide for the Identification of Plant Pathogenic Bacteria, 2nd ed. St. Paul, MN: APS Pr. p 44-59.

Harrison MD, Franc GD, Maddox DA, et al. 1987. Presence of Erwinia carotovora in surface water in North America. J Appl Bacteriol 62:565-70.

Powelson ML. 1985. Potato early dying disease in the Pacific Northwest caused by Erwinia carotovora pv. carotovora and $E$. carotovora pv. atroseptica. Am Potato J 62:173-6. ported in other potato-growing regions, and may be more of a problem in Kern County due to the routine fumigation of potato production soils and warm temperatures. If projected temperature increases due to global warming are correct, then losses from lenticel rot and Erwinia early dying can be expected to increase in the future.

J.J. Farrar is Professor, Department of Plant Science, California State University, Fresno; J.J. Nunez is Advisor, UC Cooperative Extension, Kern County; and R.M. Davis is Professor and Cooperative Extension Specialist, Department of Plant Pathology, UC Davis. We thank the California Potato Research Advisory Board for research funding.

Powelson ML, Apple JD. 1984. Soil and seed tubers as sources of inoculum of Erwinia carotovora subsp. carotovora for stem soft rot of potatoes. Phytopathol 74:429-32.

Romberg MK, Davis RM, Nunez JJ, Farrar JJ. 2002. Sources and prevention of Erwinia early dying of potato in Kern County, California. Phytopathol 92 (Supp):S70.

Rowe RC, Davis JR, Powelson ML, Rouse DI. 1987. Potato early dying: Causal agents and management strategies. Plant Dis 71:482-9.

Sessitch A, Reiter B, Pfeifer U, Wilhelm E. 2001. Cultivation-independent population analysis of bacterial endophytes in three potato varieties based on eubacterial and Actinomyces-specific PCR of 16S rRNA genes. FEMS Microbiol Ecol 39:23-32. 